\title{
Impact of infertility on marital relationships among infertile couples attending OPD of a tertiary health care centre
}

\author{
Chhaya Kushwaha $^{1}$, Parul Sinha ${ }^{1 *}$, Uma Gupta ${ }^{2}$, Kumkum Srivastava ${ }^{1}$
}

${ }^{1}$ Department of Obstetrics and Gynecology, ERA University, Lucknow, Uttar Pradesh, India
${ }^{2}$ Department of Obstetrics and Gynecology, Mayo Medical College, Lucknow, Uttar Pradesh, India

Received: 03 January 2018

Accepted: 31 January 2018

*Correspondence:

Dr. Parul Sinha,

E-mail: drparulanand@gmail.com

Copyright: (c) the author(s), publisher and licensee Medip Academy. This is an open-access article distributed under the terms of the Creative Commons Attribution Non-Commercial License, which permits unrestricted non-commercial use, distribution, and reproduction in any medium, provided the original work is properly cited.

\begin{abstract}
Background: There is little empirical literature on the effects of infertility on marital relationships in India. This study was sought to examine the impact of infertility on the marital relationships of the couple at Eras Lucknow Medical College and Hospital.

Methods: This is a descriptive cross-sectional design conducted on infertile women presenting in OPD (outpatient department) of Obstetrics and Gynecology Department of Era's Lucknow Medical College and Hospital. A selfdeveloped questionnaire was used for collecting data for the study. The questionnaire was divided into 5 sections: A to E. Data was presented in the form of descriptive statistics such as proportion and percentage.

Results: This study revealed that infertility affected the sexual life of participants as it was reported that even though they still had regular sexual intercourse with their partners after realising they were infertile (64.5\%), sex was only for the purpose of reproduction and not for mutual sexual satisfaction (13\%). Sexual intercourse was reported to be unfulfilling as well as unenjoyable (16.4\%). The psychological well-being of participants (29.60\%) and stability within marital unions were also negatively affected by infertility, resulting in quarrels (13\%).

Conclusions: Infertility has numerous negative implications for marital relationship. Thus, infertile persons should not be only physically examined and treated for infertility but should also be given counselling to lessen the psychological trauma attached to infertility.
\end{abstract}

Keywords: Infertile couples, Infertility, Marital relationship

\section{INTRODUCTION}

Roupa et al described infertility as the inability to procreate after trying for 1 year without the use of birth control methods while having normal sexual intercourse. ${ }^{1}$ The World Health Organisation also describes infertility as the inability of a sexually active, non-contraception using couple to achieve pregnancy in 1 year. $^{2}$

Even though male infertility is acknowledged to exist, women are ultimately held responsible for a couple's inability to reproduce. ${ }^{3}$ According to Cooper, a couple's sexual relationship is often the area of their life that is most negatively affected by infertility. ${ }^{4}$ Love making, which initially in marriage is a warm, loving, intimate and physically pleasurable experience becomes a dreaded chore, serving only as a means to an end and even continues to result in futility. To worsen situations, sex often becomes the battleground where a couple's fears, anxieties and depressions are played out. ${ }^{4}$

Infertility has been linked to conflicts in marital relationship. Couples may avoid interactions with their friends particularly those who are pregnant and families who have children but can entirely not avoid conflict in the relationship arising due to their infertile status. ${ }^{4}$ 


\section{METHODS}

This is a Descriptive cross-sectional design conducted on infertile women presenting in OPD (outpatient department) of Obstetric and Gynaecology Department of Era's Lucknow Medical College and Hospital.

This study seeks to examine the effects of infertility on martial relationships among infertility clients in Out Patient Department, in terms of sex life, psychological wellbeing, communication as well as conflicts and to determine whether any of the background characteristics is associated with psychological trauma due to infertility.

A self-developed questionnaire will be used for collecting data for the study. The questionnaire is divided into 5 sections: A to E. Section A comprises background characteristics of participants consisting of age, educational level, religion and ethnicity.

Section B focuses on self-reported effects of infertility on sex life. Issues considered will be regularity of sexual intercourse, sex only becoming an act for procreation and not for mutual satisfaction and the nature of sexual intercourse, after the realisation of infertility in the union.

Section $\mathrm{C}$ focuses with the self- reported effects of infertility on psychological wellbeing of participants. Psychological trauma due to infertility, expression of the psychological trauma.

Section D focuses on infertility and communication while Section E focuses on effects of infertility on the stability of martial relationship. This section will consider the quarrels, fights, and threats of divorce in marital relationships due to infertility. The questionnaires will be given to participants with formal education to fill by themselves, while the question will be read to participants without formal education to respond to them.

\section{Inclusion criteria}

- Married females

- Females with primary infertility

- Females with secondary infertility.

\section{Exclusion criteria}

- Divorced woman

- Woman in live in relationship.

\section{Statistical analysis}

Data will be present in the form of descriptive statistics such as proportion and percentage. Numerical data will be summarised as mean and SD. Appropriate statistics test such as chi square will be noted to test associations etc

\section{RESULTS}

The result of the study indicated that maximum patients were of age 20-29 (76.97\%). More than half were having only primary education $(52.70 \%),(71 \%)$ were Hindus.

Table 1: Background characteristics of participants.

\begin{tabular}{|c|c|c|}
\hline Characteristic & Frequency & Percent \\
\hline \multicolumn{3}{|l|}{ Age } \\
\hline $20-29$ & 117 & 76.97 \\
\hline $30-39$ & 25 & 16.44 \\
\hline $40-49$ & 10 & 6.57 \\
\hline \multicolumn{3}{|l|}{ Education level } \\
\hline No formal education & 48 & 31.57 \\
\hline Primary education & 80 & 52.63 \\
\hline Secondary education & 24 & 15.78 \\
\hline \multicolumn{3}{|l|}{ Religion } \\
\hline Hindu & 108 & 71 \\
\hline Muslim & 40 & 26.31 \\
\hline \multicolumn{3}{|l|}{ Christian } \\
\hline Others & 4 & 2.63 \\
\hline
\end{tabular}

Table 2: Self-reported effects of infertility on sex life in martial relationship.

\begin{tabular}{|c|c|c|}
\hline Statement & Frequency & Percent \\
\hline \multicolumn{3}{|l|}{ Regular sexual intercourse } \\
\hline Yes & 98 & 64.47 \\
\hline No & 54 & 35.52 \\
\hline \multicolumn{3}{|c|}{$\begin{array}{l}\text { Sex is only for procreation but not for mutual } \\
\text { satisfaction }\end{array}$} \\
\hline Yes & 20 & 13.15 \\
\hline No & 132 & 86.84 \\
\hline \multicolumn{3}{|l|}{ Nature of sexual intercourse } \\
\hline Unfulfilling and unenjoyable & 25 & 16.44 \\
\hline Fulfilling and enjoyable & 85 & 55.92 \\
\hline Don’t know & 58 & 38.15 \\
\hline
\end{tabular}

$64.47 \%$ had regular sexual intercourse. $13.15 \%$ reported that sex was only for self-procreation. $16.44 \%$ were unfulfilling and unenjoyable.

Table 3: Self-reported effects of infertility on psychological well-being of individuals.

\begin{tabular}{|c|c|c|}
\hline Statement & Frequency & Percent \\
\hline \multicolumn{3}{|c|}{ Psychological trauma due to infertility } \\
\hline Yes & 45 & 29.60 \\
\hline No & 107 & 70.39 \\
\hline \multicolumn{3}{|c|}{ Expression of psychological trauma } \\
\hline Crying for days & 72 & 47.36 \\
\hline $\begin{array}{l}\text { Blaming one-self for being } \\
\text { infertile }\end{array}$ & 60 & 39.47 \\
\hline $\begin{array}{l}\text { Quarrelling with people over } \\
\text { the least provocation }\end{array}$ & 20 & 13.15 \\
\hline \multicolumn{3}{|l|}{ Contemplation of suicide } \\
\hline Yes & 11 & 7.23 \\
\hline No & 141 & 92.76 \\
\hline
\end{tabular}


Psychological trauma was seen in $70.39 \%$. $47.36 \%$ expressed their trauma through crying for days without eating. $39.47 \%$ blamed themselves for being infertile. $13.15 \%$ reported picking up quarrels. $7.23 \%$ reported that the contemplated suicide.

Table 4: Chi-square test of association between psychological trauma and background characteristics of participants.

\begin{tabular}{|c|c|c|}
\hline $\begin{array}{l}\text { Background } \\
\text { characteristics }\end{array}$ & $\begin{array}{l}\text { Chi-square } \\
\left(\chi^{2}\right)\end{array}$ & p-value \\
\hline Age & 29.8 & $<0.001$ \\
\hline Education level & 46.5 & $<0.001$ \\
\hline Religious affiliation & 7.33 & 0.026 \\
\hline
\end{tabular}

This study revealed that infertility affected the sexual life of participants as it was reported that even though they still had regular sexual intercourse with their partners after realising they were infertile $(64.5 \%)$, sex was only for the purpose of reproduction and not for mutual sexual satisfaction (13\%). Sexual intercourse was reported to be unfulfilling as well as unenjoyable $(16.4 \%)$. The psychological well-being of participants (29.60\%) and stability within marital unions were also negatively affected by infertility, resulting in quarrels (13\%).

Table 5: Chi-square test of association between contemplation of suicide and background characteristics of participants.

\begin{tabular}{|lll|}
\hline $\begin{array}{l}\text { Background } \\
\text { characteristics }\end{array}$ & $\begin{array}{l}\text { Chi-square } \\
\left(\chi^{2}\right)\end{array}$ & p-value \\
\hline Age & 0.163 & 0.922 \\
\hline Level of education & 19.4 & $<0.001$ \\
\hline Religious affiliation & 0.859 & 0.651 \\
\hline
\end{tabular}

Level of education had significant $p$-value $<0.001$

\section{DISCUSSION}

The study found that more females than males, attended infertility clinic at the health facility. This is in agreement with Fledderjohann's argument that females are usually blamed for infertility. As such, they were mostly the persons who sought treatment for the couple's inability to reproduce. The study found that even though the participants had regular sexual intercourse, sexual intercourse between the couples was merely for procreation purposes but not for mutual satisfaction. The majority of the participants reported that sexual intercourse was unfulfilling and not enjoyable. This finding is consistent with findings of Zegers-Hochschild et al. ${ }^{5}$ The study further found that the majority of the participants suffered psychological trauma due to their infertility. This was usually expressed through consistent cries and self-accusation or self-condemnation as well as being overly sensitive. Hence, infertility negatively affected the psychological well-being of participants. This is similar to the findings of a study conducted by
Peterson et al in which the authors argued that infertility is negatively related to the psychological functioning of both women and men. ${ }^{6}$

It came out that even though majority of the participants experienced psychological trauma due to their condition, only a few contemplated or considered committing suicide as a permanent solution to the condition. Thus, most of the participants never contemplated suicide and this may be due to a number of factors including knowledge of treatment for the condition, education as well as possible availability of friends and relatives who may serve as source of comfort and encouragement for the participants.

It also came out that contemplation of suicide due to infertility was associated with only level of education of participants. This may be due to the fact that education may be a source of enlightenment concerning the various options of treatment for the condition. The study also revealed that communication in the marital relationships of participants was damaged. Hence, the assumption that communication between couples which has positive impacts on their marital relationships becomes questionable in the face of infertility where communication between the couple becomes strained. ${ }^{7}$

The study found no association between psychological trauma and any of the background characteristics of participants. This may imply that irrespective of the background of the participant, he or she may be well susceptible to psychological trauma as a result of infertility.

Infertility was also found to have impinged on the stability of marital relationships by causing conflicts in the marital relationships of participants. Participants had misunderstandings with their partners over their inability to give birth to children even though majority had never fought with their partners or threaten them with divorce. This confirms the assertion made by Koenig et al that infertility has a link with conflicts in marital relationships. ${ }^{8}$

Tufts et al also note that marital relationships may suffer, especially, when couples are dealing with infertility and may thus avoid interactions with their friends particularly those who are pregnant as well as families who have children. ${ }^{9}$ Thus, couples cannot entirely avoid conflict in their marital relationships due to their infertile status.

\section{CONCLUSION}

Infertility has numerous negative implications for marital relationship. Thus, infertile persons should not only be physically examined and treated for infertility but should also be given counselling to lessen the psychological trauma attached to infertility.

Funding: No funding sources 
Conflict of interest: None declared

Ethical approval: The study was approved by the Institutional Ethics Committee

\section{REFERENCES}

1. Roupa Z, Polikandrioti M, Sotiropoulou P, Faros E, Koulouri A, Wozniak G, et al. Causes of infertility in women at reproductive age. Health Sci J. 2009;3(2):80-7.

2. World Health Organisations. Infertility definitions and terminology. 2014. Available at http://www.who.int/reproductivehealth/topics/infertil ity/definitions/en/

3. Fledderjohann JJ. Zero is not good for me: implications of infertility in Ghana. Human Reprod. 2012;27(5):1383-90.

4. Cooper S. Sex, relationships and infertility: fact sheet 14. Resolve, Mclean; 2007. Available at http://familybuilding.resolve.org/site/DocServer/14_ Sex_Marriage_and_Infertility.pdf?docID=5704 Accessed 12 December 2017

5. Zegers-Hochschild F, Nygren KG, Adamson GD. The international committee monitoring assisted reproductive technologies (ICMART) glossary on ART terminology. Fertil Steril. 2006;86(1):16-9.

6. Peterson BD, Newton CR, Rosen KH. Examining congruence between partners' perceived infertilityrelated stress and its relationship to marital adjustment and depression in infertile couples. Fam Process. 2003; 42(1):59-70.

7. Clementini E, Palka C, Lezzi I. Prevalence of chromosomal abnormalities in 2078 infertile couples referred for assisted reproduction technologies. Human Reprod. 2005;20(2):437-42.

8. Koenig MA, Stephenson R, Ahmed S. Individual and contextual determinants of domestic violence in North India. Am J Pub Health. 2006;96(1):132-8.

9. Tufts KA, Clements PT, Karlowicz KA. Integrating intimate partner violence content across curricula: developing a new generation of nurse educators. Nurse Educ Today. 2009;29(1):40-7.

Cite this article as: Kushwaha C, Sinha P, Gupta U, Srivastava K. Impact of infertility on marital relationships among infertile couples attending OPD of a tertiary health care centre. Int J Reprod Contracept Obstet Gynecol 2018;7:1164-7. 